\title{
NOVĚ OBJEVENÉ HRADIŠTĚ ČERŤÁK U OBCE SOVOLUSKY V KONTEXTU HALŠTATSKÉHO OSÍDLENÍ REGIONU
}

\author{
Filip Prekop* - Petr Krištuf**
}

* Národni památkový ústav, územni odborné pracovištè v Lokti. Kostelni 81, 35733 Loket, prekop.filip@npu.cz.
** Katedra archeologie, Filozofická fakulta Západočeské univerzity v Plzni, Sedláčkova 15, 30614 Plzeň,pkristuf@_kar.zu.cz.

\begin{abstract}
The discovered hillfort "Certak" and surroundigs settlement from final hallstat period in Karlovy Vary district. This paper presents a new hillfort site which is situated on top of „Čert’ák“ Hill (651 m n. m.), Sovolusky municipality, Karlovy Vary district. It has been identified with the help of a digital terrain model based on Airborne Laser Scanning (LiDAR). Two separate lines of stone ramparts have been confirmed on top of the Čert'ák Hill, formed by a significant right bank meander in the upper course of the river Střela. The inner area reaches 1.4 ha and the external enclosed area spreads to $2.3 \mathrm{ha}$. Subsequent field research yielded a collection of more than 500 pottery fragments from the Late Hallstatt period. The dispersion of finds shows relatively intensive settlement. The paper also discusses other sites in the surrounding region which date to the same period. The Hallstatt settlement seems to have been a structurally connected complex in the presented area.
\end{abstract}

Keywords: Late Hallstatt period, Hillfort with Embankments, Aerial Laser Scanning, ceramics, Karlovy Vary Region

Abstrakt: Práce představuje zcela nově identifikované výšinné ohrazené sídliště na vrchu Čert’ák (651 m n. m.) u obce Sovolusky, okr. Karlovy Vary. Za jeho lokalizaci vděčíme volně dostupnému digitálnímu modelu reliéfu pro celé území České republiky, vytvořeného Českým zeměměřčským a katastrálním úřadem. Objevená lokalita patří do skupiny, jež dokládá zvýšenou lidskou prrítomnost v oblasti během období pozdní doby halštatské. Dvoudílná plocha o celkovém rozsahu 3,7 ha zaujímá celou vrcholovou plošinu tohoto výrazného pravobřežního meandru řeky Střely. Revize existujících terénních porušení a čtveřice zjišt’ovacích sond přinesla relativně bohatý soubor keramických fragmentů a rovnoměrně se vyskytující kulturní vrstvu ve vnitřní i vnější ohrazené ploše. Konstrukce ohrazení nebyla dosud zkoumána.

Klíčová slova: pozdní doba halštatská, výšinné ohrazené sídliště, letecké laserové skenování, keramika, Karlovarský kraj

https://doi.org/10.46283/musarch.2021.1.2.06

\section{1. Úvod}

Naše práce se věnuje objevu a prvotní charakteristice výšinného ohrazeného sídliště z vrchu Čert’ák u Sovolusk, na jihovýchodním okraji okresu Karlovy Vary (obr. 1). Lokalita je nejnovějším přírůstkem do skupiny nově objevených výšinných poloh se stopami pravěkého osídlení v této oblasti, které se podrobněji věnujeme od roku 2014. Na všech byly identifikovány relikty ohrazení v podobě valů. Můžeme je tedy zařadit do kategorie hradiště, i když tento termín nemusí nutně vypovídat o interpretaci jejich původního účelu. Jedná se o dvojici lokalit v okolí obce Valeč, tedy konkrétně o hradiště na vrchu Orlík a Šibeniční vrch (Prekop - Krištuf - Peksa a kol. 2017). Následně byla v tomto regionu objevena a prozkoumána další výšinná ohrazená poloha na Kružínském vrchu u obce Skytaly (Prekop-Krištuf - Peksa 2018). Na všech zmiňovaných lokalitách byly mimo jiné zachyceny stopy využívání poloh v době halštatské, resp. z přelomu pozdní doby bronzové a doby halštatské. Okolí nově objevených hradišt’ lze popsat také jako 


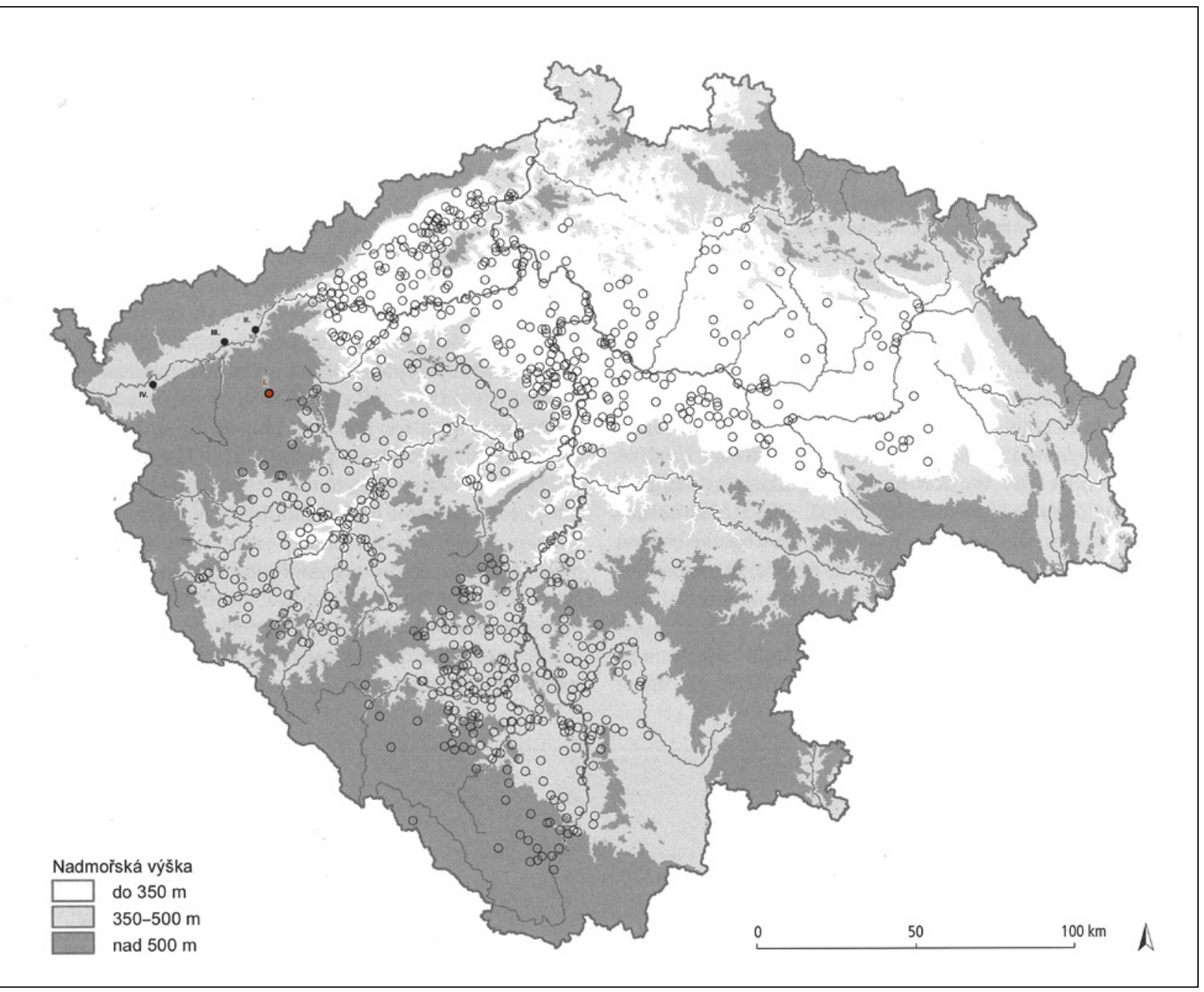

Obr. 1. Lokalizace zkoumané lokality na přehledné mapě známých katastrů s potvrzeným osídlením z pozdní doby halštatské až časné doby laténské. Doplněny lokality: (I.) Sovolusky, (II.) Velichov - Liščí vrch, (III.) Karlovy Vary Bohatice, (IV.) Libavské Údolí - Kolová. Zdroj: Venclová (ed.) a kol. 2008, 101, doplnil F. Prekop.

Fig. 1. The map of Late Hallstatt/Early La Tène settlement sites in Bohemia. New sites added: I. Sovolusky, (II.) Velichov Liščí vrch, (III.) Karlovy Vary - Bohatice, (IV.) Libavské Údolí - Kolová. Source: Venclová (ed.) a kol. 2008, 101, added by F. Prekop.

jihovýchodní úpatí Doupovských hor, se kterými je pojí i stejný geologický původ coby třetihorních vyvřelin (Matěju - Hradecký - Melichar 2010). Z pohledu poznání osídlení oblasti nově objevená skupina společně s dřive známými lokalitami Chyše - Na střelnici (Soukupová - Baštová 1984, 164-166) a Podštěly - Jezerský vrch (Soukupová - Baštová 1984, 164-166; Augustinová 2014) zajímavě vyplňuje prostor mezi dvěma lokalitami nadregionálního významu. Máme

- Obr. 2. Známé lokality z Ha D2-LtA oblasti Horního toku Střely a sekundární naleziště zlata. 1 - Sovolusky - Čert'ák; 2 - Sovolusky - pohřebiště; 3 - Mocenské centrum Vladař; 4 - Chyše - Na střelnici; 5 - Podštěly - Jezerský vrch; 6 Podštěly - cihelna; 7 - Manětín - Hrádek; 8 - Nečtiny - hrad; 9 - Žlutice město; 10 - Novosedly; A - Veselov, pylový profil. Zdroj: Chytráček - Metlička 2004, mapa 16, doplnil F. Prekop.

- Fig. 2. Known Late Hallstatt/Early La Tène sites in the upper part of Střela River and secondary sites of gold deposits. 1 - Sovolusky - Čert’ák; 2 - Sovolusky - cemetery; 3 - The power center Vladař hillfort; 4 - Chyše - Na střelnici; 5 - Podštěly - Jezerský hill, hillfort; 6 - Podštěly - brickyard; 7 - Manětín - Hrádek; 8 - Nečtiny - castle; 9 Žlutice town; 10 - Novosedly; A - Veselov - palynological sediment. Source: Chytráček - Metlička 2004, map 16, added by F. Prekop. 


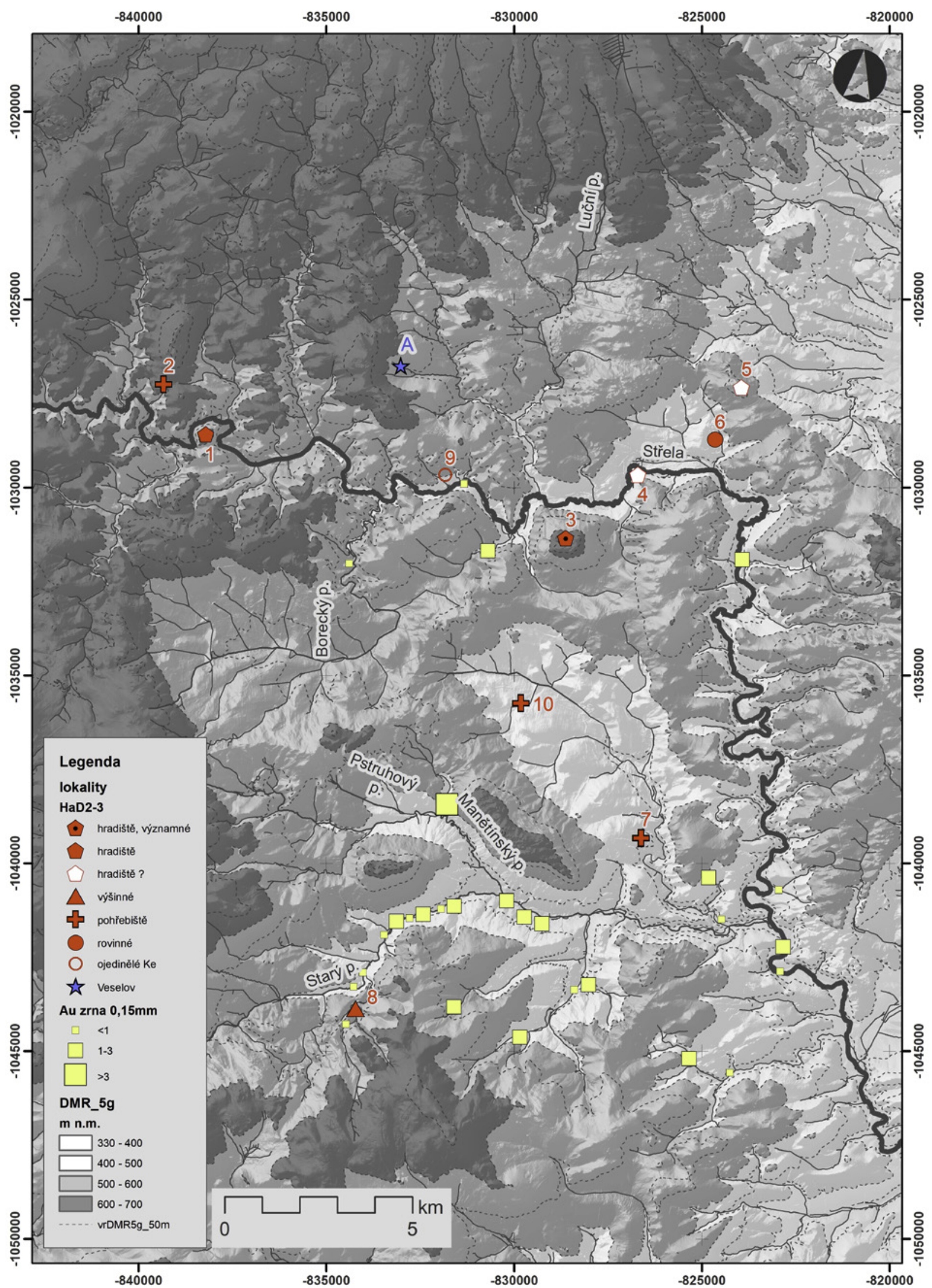


na mysli vrch Rubín u Podbořan (Čtverák et al. 2003, 67-68) na severovýchodě a vrch Vladař na jihozápadně (Chytráček - Danielisová - Pokorný a kol. 2012).

Vrch Čert’ák se z uvedené skupiny poněkud vymyká. Z prostorového hlediska je jako jediný vysunutý $10 \mathrm{~km}$ západně od vrchu Vladař, čímž je zatím nejzápadněǰ̌ím hradištěm tohoto sídelního regionu (obr. 2). Oproti předchozím lokalitám Čert’ák odlišuje geologické podloží, které zde je tvořené středně silně metamorfovaným svorem tepelského krystalinika. ${ }^{1}$ Jeho vrcholek leží na souřadnicích $50.0907917 \mathrm{~N}, 13.0720750 \mathrm{E}$ a dosahuje nadmořské výšky $651 \mathrm{~m} \mathrm{n} . \mathrm{m}$. V roce 2018 se při analýze digitálního modelu reliéfu podařilo jednomu z autorů článku (F. Prekopovi) rozpoznat na vrchu Čert’ák valové liniové útvary pravděpodobně antropogenního původu. Situaci potvrdil terénní revizí v červenci téhož roku. Kromě jednoznačné identifikace ohraničujících valů, získal první zlomky pravěké keramiky (obr. 14). Tato zjištění nás vedla k závěru, že na vrchu Čert’ák u Sovolusk mohlo v pravěku existovat ohrazené výšinné sídliště podobné těm, která byla $\mathrm{v}$ minulých letech objevena a zkoumána na Valečsku. K důkladnému povrchovému průzkumu a mikrosondáži lokality jsme přistoupili v srpnu téhož roku. Dokončení mapování terénních reliktů proběhlo v dubnu 2019, a to s ohledem na př́znivější vegetační podmínky.

Při snaze nalézt vrch Čert’ák v současných mapách hrozí záměna se sousedním Čertovým vrchem, který leží přibližně $650 \mathrm{~m}$ jihovýchodním směrem. Nepřehledná situace vznikla pravděpodobně s novým pojmenováním obcí a toponym českého pohraničí v souvislosti s vysídlením německého obyvatelstva po druhé světové válce. $S$ termínem Čert’ák se totiž poprvé setkáváme až na mapě z roku 1954, jenž vznikla v rámci řady děl topografického systému S-1952, a to konkrétně na listu M33-63C. ${ }^{2}$ Na nejstarším dostupném mapovém díle z 60. let 18. století, tzv. Prvního vojenského mapování se dvojice podobných vrchů nerozlišovala a oba byly shodně pojmenované Teufels. B., tedy Čertův vrch. ${ }^{3} \mathrm{Na}$ Císařských otiscích stabilního katastru z roku 1842 nese dnešní vrch Čert’ák označení Teufelberg / Čertův vrch, zatímco dnešní Čertův vrch byl zahrnutý pod označením Bei der langen Wiese / U dlouhé louky. ${ }^{4}$ Třetí vojenské mapování ze 70. let 19. století rovněž podtrhuje dominantní roli námi popisovaného vrchu jako Teufelsberg, zatímco druhý z vrcholků není pojmenovaný vůbec. ${ }^{5}$

\section{Metody výzkumu}

Náš výzkum využíval kombinaci destruktivních a nedestruktivních metod. Poloha byla objevena na volně dostupném digitálním modelu reliéfu krajiny ČR, kterou pod názvem "Analýzy výškopisu” poskytuje všem uživatelům internetu ve svém geoprohližeči Český úřad zeměměřický a katastrální. ${ }^{6}$ Digitální model reliéfu je plošně souvislou vrstvou pixelů, které odpovídají skutečné ploše zemského povrchu o rozměrech $2 \times 2 \mathrm{~m}$. Při snaze pochopit členění lokality jsme museli přsstoupit ke zpracování vlastního digitálního modelu okolí lokality o vy̌šsí přesnosti. Ze zakoupeného mračna bodů po robustní filtraci jsme pomocí algoritmu natural neighbour získali model reliéfu, jehož základní buňka odpovídala 0,5 × 0,5 m snímaného povrchu. Využili jsme softwarové prostředí ArcMap 10.2.2.

Zobrazený digitální model terénu vrchu a jeho okolí se skládá ze trrí vrstev (obr. 5). Podkladem je jednoduchý stínovaný model - hillshade s trojnásobným zvětšením hodnot nadmořské výšky. Pro potlačení ostrých kontrastů světla a stínu jsme překryli model vrstvou lokálního modelu reliéfu a rovnoměrným osvícením metodou skyview factor. Archeologickou interpretaci objektů digitálního modelu jsme následně verifikovali terénní prospekcí a doplnili ji o další relevantní pozorování (obr. o). Mezi ně patří průběh liniového opevnění, revidované vývraty stromů a místa výskytu movitých nálezů.

Terénní zjištění pochází ze třech terénních akcí. Kromě prvotního sběru movitých nálezů, dne 18. července 2018, byla těžištěm pětidenní kampaň ve dnech 23. až 27. července téhož roku. V prostoru ohrazené polohy byly položeny 4 zjišt'ovací sondy o rozměru $1 \times 1 \mathrm{~m}$. Situace byla standardně kresebně a fotograficky dokumentována. Z vybraných

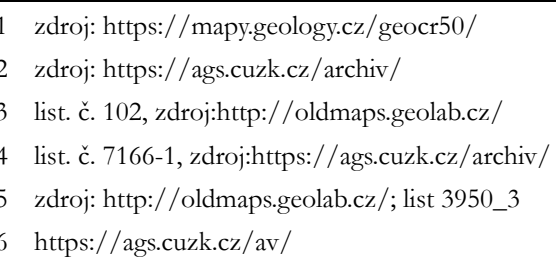




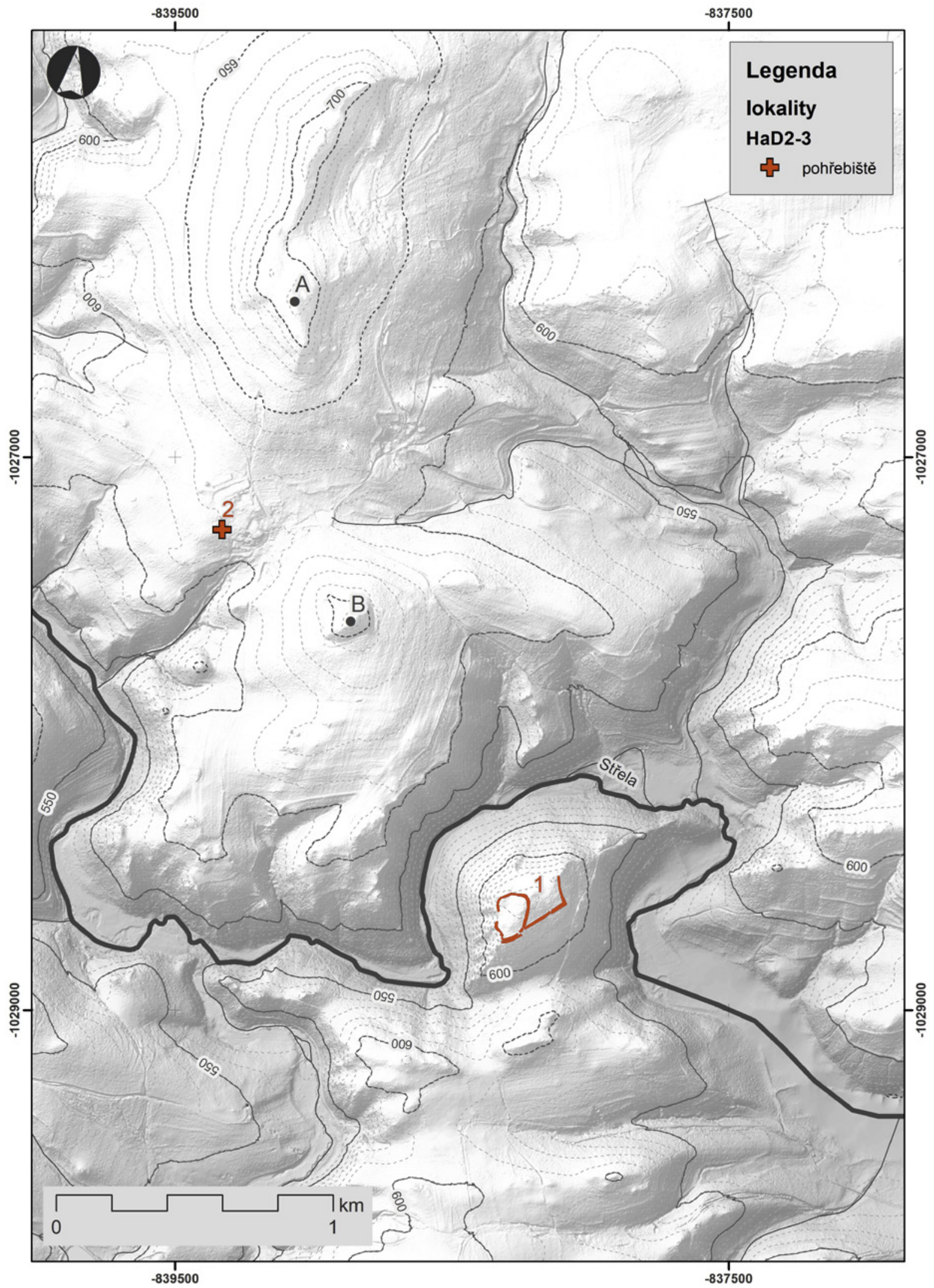

Obr. 3. Prostorový vztah objeveného ohrazeného sídliště na vrchu Čert’ák (1) a pohřebiště v Sovoluskách (2). Výrazný Jesínecký vrch (A) a dílčí kupa Muriňák (B). Vytvořil F. Prekop.

Fig. 3. The spatial relation between Čert'ák hillfort (1) and Sovolusky cemetery (2). The hills mentioned in text: (A) Jesínecký vrch, (B) Muriňák. Created by F. Prekop. 


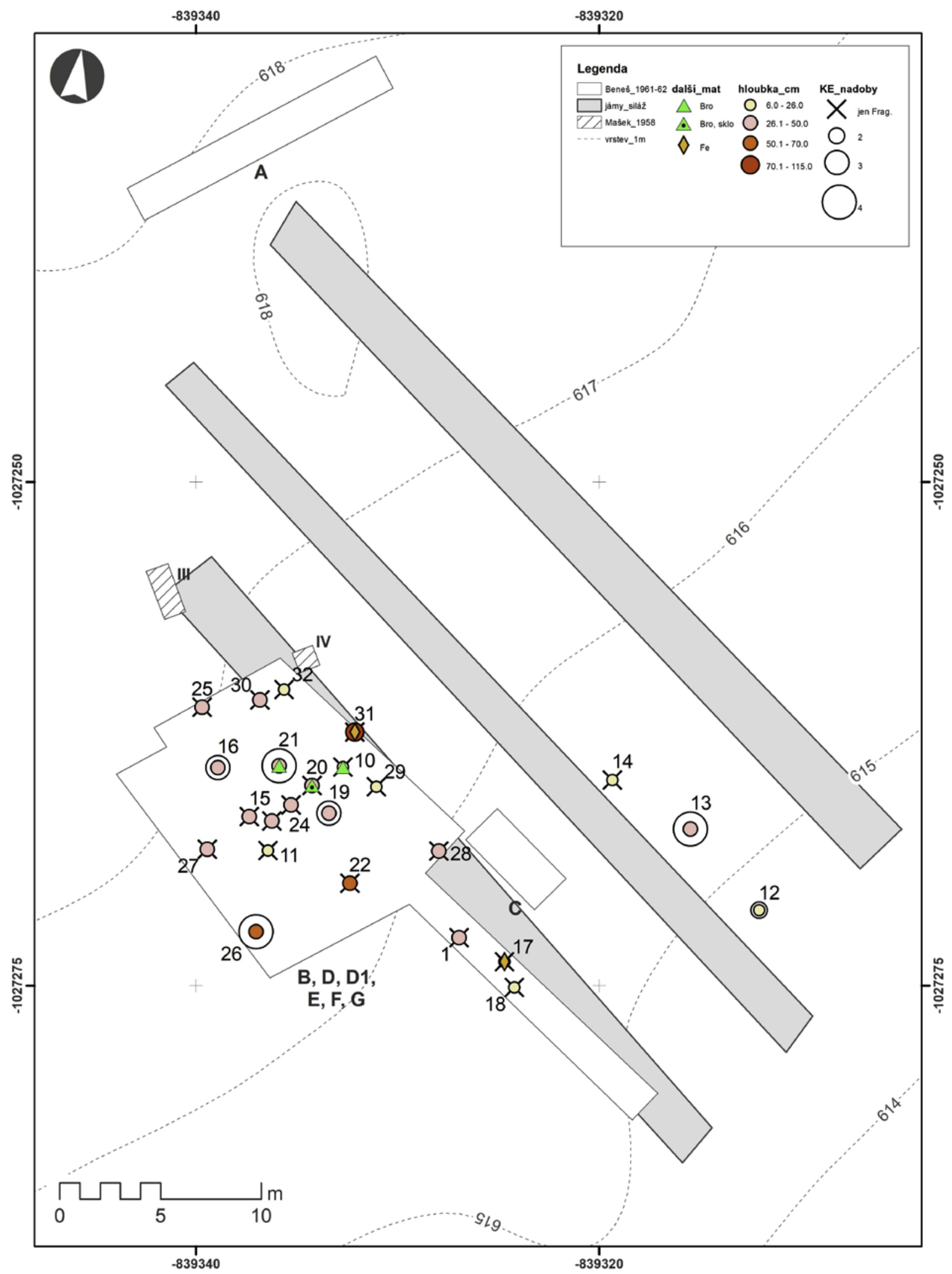

Obr. 4. Celkový plán pohřebiště v Sovoluskách. Na základě plánu A. Beneše (Beně̌ 1969a, 136), překreslil F. Prekop. Fig. 4. Sovolusky - cemetery. Source: Beneš 1969a, 136. Redrawed by F. Prekop. 


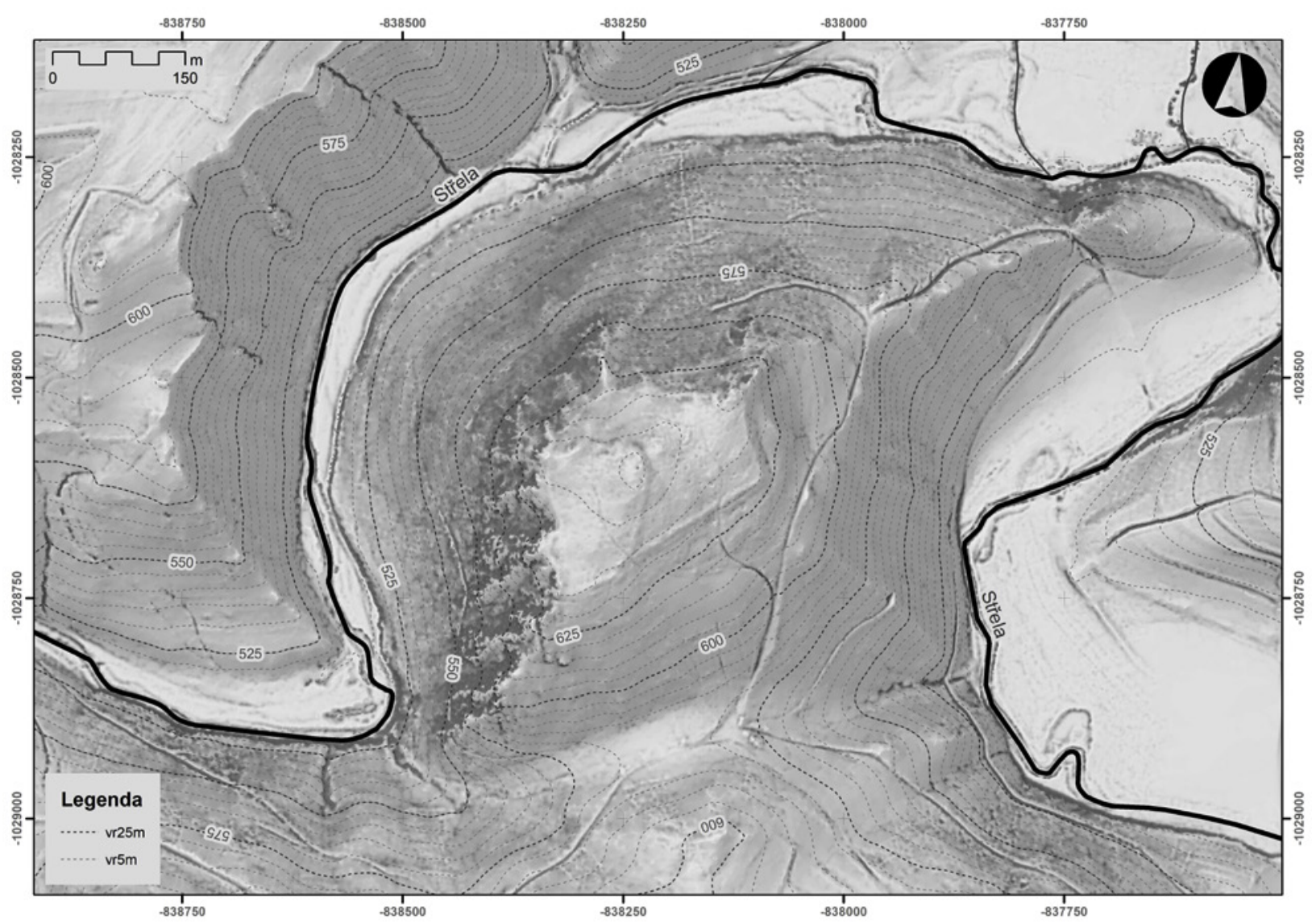

Obr. 5. Podrobný digitální model reliéfu vrchu Čert’ák a nejbližšího okolí, společně s odvozeným vrstevnicovým plánem z dat leteckého laserového snímkování, zdroj: data leteckého laserového skenování ČÚZK. Vytvořil F. Prekop

Fig. 5. The detailed digital terrain model of Čert'ák Hill and its surroundings together with a derived contour plan. Created by F. Prekop, data source: Airborne laser scanning by The Czech Geodetic and Cadastral Office (ČÚZK).

Created by F. Prekop.

uloženin jsme také odebrali vzorky na environmentální rozbor (Kočár 2019). Lokalitu jsme podrobili i detektorovému průzkumu s využitím př́ístroje Minelab Equinox 800. Poslední část našeho průzkumu jsme realizovali v dubnu 2019, kdy jsme se ve vegetačně příznivém období soustředili na zaměření nemovitých objektů lokality.

Typologické a chronologické vyhodnocení keramického souboru bylo spojeno s podrobnou dokumentací vybraných fragmentů pomocí laserového profilovače LAP, který vyvinul Peter Demján a Vladimír Držík. Př́istroj pracuje na principu promítání a následném snímání roviny protilehlých laserových paprsků na uvedený artefakt. Z uvedené křivky dochází $\mathrm{k}$ rekonstrukci profilu artefaktu a dalších měřitelných a obrazových hodnot. Vzniká tak standardizovaná analytická dokumentace artefaktu a jedinečný databázový záznam každého dokumentovaného fragmentu. ${ }^{7}$

\section{Popis lokality}

Přirozený tvar vrchu Čert’ák je formovaný téměř úplným obtékáním řeky Střely (obr. 5). Vrcholové plató zaujímá tvar nepravidelné elipsy s hlavní osou ve směru JZ-SV. Délka hlavní osy činí $325 \mathrm{~m}$ a vedlejší cca 175 m. Př́kré svahy nalezneme na západě, kde je odhalilo erozní působení řeky, zatímco mírnější svahy jsou na severní a východní straně meandru. Jižní svahy vrchu klesají do hlubokého př́istupového sedla, jež se rozprostírá o 70 m níže, okolo vrstevnice $580 \mathrm{~m} \mathrm{n} . \mathrm{m}$. 


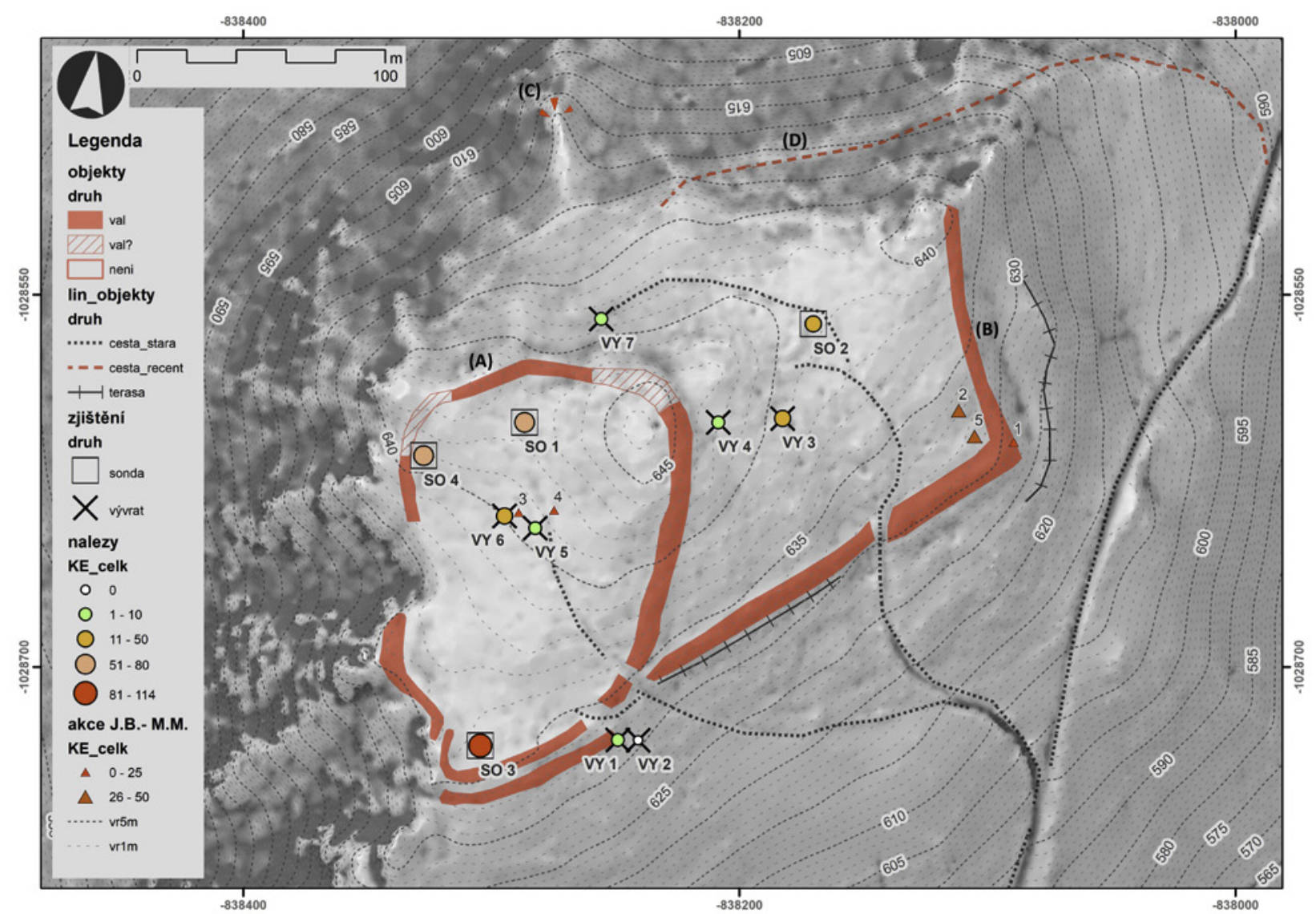

Obr. 6. Celkový plán ohrazeného sídliště na vrchu Čert’ák a rozsah zjištění. Dvojice linie valů jsou hlavní pozorovatelnou nemovitou součástí lokality. Sestavil F. Prekop

Fig. 6. The general plan of the hillfort at Čert'ák, with two lines of stone ramparts. Created by F. Prekop.

Hlavními antropogenními objekty lokality jsou dvě linie kamenných valů. Jejich šířka nepřesahuje $2 \mathrm{~m}$ a dnešní výška se pohybuje od několika málo centimetrů na severu po maximálních $0,5 \mathrm{~m}$ na jihozápadě (obr. 10). Vnitřní linie má nepravidelný půdorys ledvinovitého tvaru (obr. 6: $A$ ). Kopíruje tvar výrazné západní hrany vrchu a spojuje ji se samotným vrcholem, od kterého se stáći $\mathrm{k}$ severu a následně opět k západu. Kopíruje také průběh terénní hrany vrcholového plató na jihu i na severu. Při detailnějším terénním průzkumu je její průběh pozorovatelný v celém obvodě s výjimkou střední části západního okraje. Zde patrně zmizela po částečném zhroucení hrany vrchu pod náporem říční a následné svahové eroze. Nejlépe dochovaná je jihozápadní část valu. Zde nelze vyloučit pozůstatek "nálevkovité, dovnitř otevřené" brány. Rozsah vnitřní plochy hradiště odhadujeme na 1,4 ha.

Vnější linie opevnění vrchu (obr. 6: B) je patrná pouze na jižní a východní hraně vrcholové plošing, v intervalu nadmořských výšek $630-635 \mathrm{~m}$. $\mathrm{m}$. Na západě opevnění bezprostředně príiléhá k prudkému západnímu svahu. První třetina linie, cca v úseku $80 \mathrm{~m}$, kopíruje průběh vnitřního opevnění a mohla zde vytvářet cca $10 \mathrm{~m}$ široký koridor. Po mírném zatočení $\mathrm{k}$ severu, kde bohužel pozorujeme také průnik opevnění s recentními cestami, přechází linie do př́mého směru $\mathrm{k}$ severovýchodu, ve kterém se ubírá až $\mathrm{k}$ závěru plošiny, v délce cca $170 \mathrm{~m}$. Následující část vnějši linie opevnění směřující $\mathrm{k}$ severu měří téměř přesně $100 \mathrm{~m}$ a je mírně prohnutá do stř̌edu ohraničené plochy. Závěr valu přiléhá $\mathrm{k}$ dílčímu vrcholu kopce na severovýchodním okraji vrcholové plošiny. Bohužel, nic nenasvědčuje tomu, že by vnější val pokračoval i na severním nebo severozápadním svahu. Rozsah vnější ohrazené plochy odhadujeme na 2,3 ha a tím pádem celkovou ohrazenou plochu vrchu na 3,7 ha.

Ke složení ani konstrukci opevnění nemáme nyní bližší informace. Z povrchového průzkumu vyplývá, že dominantní složkou je lokální kámen (obr. 9).

V severním svahu pozorujeme další dva zajímavé objekty. Je to dílčí "vyhlídka" a relikt prístupové cesty. Vyhlídka je téměř homolovitý útvar, který je s vrcholovým plató spojený $30 \mathrm{~m}$ dlouhou a jen asi $3-4 \mathrm{~m}$ širokou šijí (obr. 6: C). 


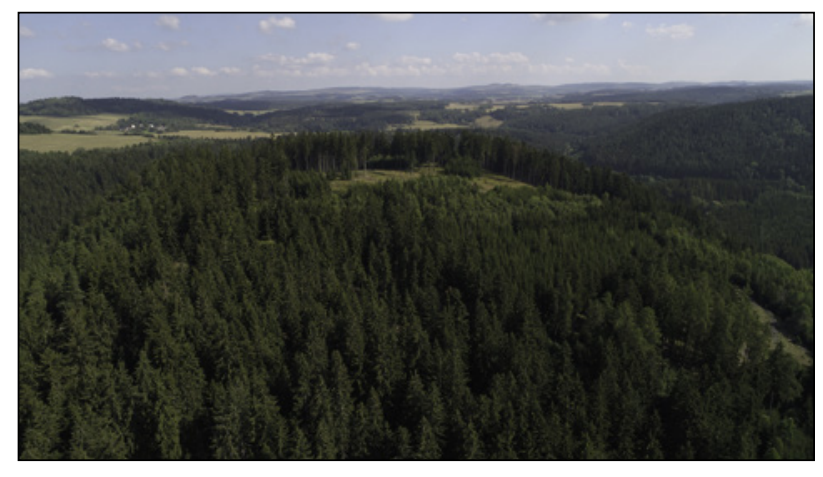

Obr. 7. Letecký pohled na vrch Čert’ák od jihu. Na vrcholové plošině jsou dobře patrné následky kůrovcové kalamity. Autor F. Prekop.

Fig. 7. An aerial view of Čert'ák Hill from the south. The clearing after bark beetle calamity is still recognizable on the top platform of the hill. Photo by F. Prekop.

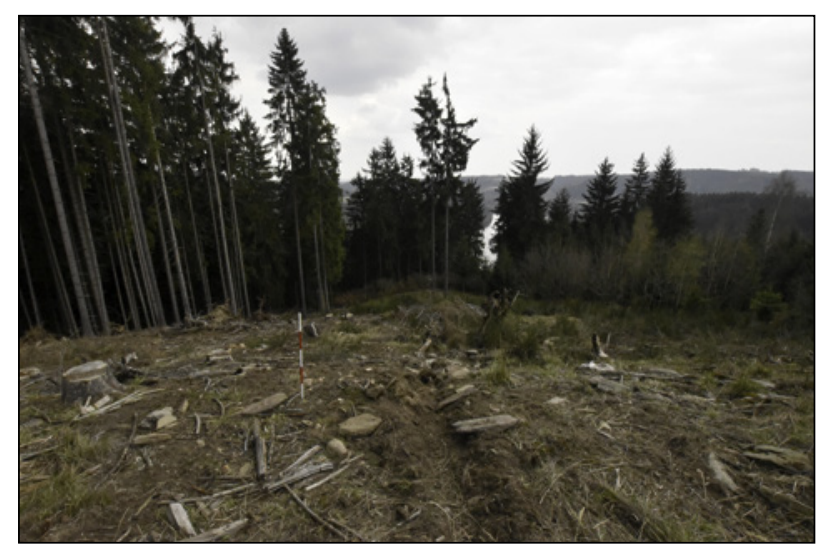

Obr. 9. Porušení jihovýchodního koutu vnější ohrazené plochy. Poloha 1, viz celkový plán, Obr. 5. Autor

$$
\text { F. Prekop. }
$$

Fig. 9. The southeast corner of the outer fortified area, damaged by logging. (position 1, in Fig. 5). Photo by

$$
\text { F. Prekop. }
$$

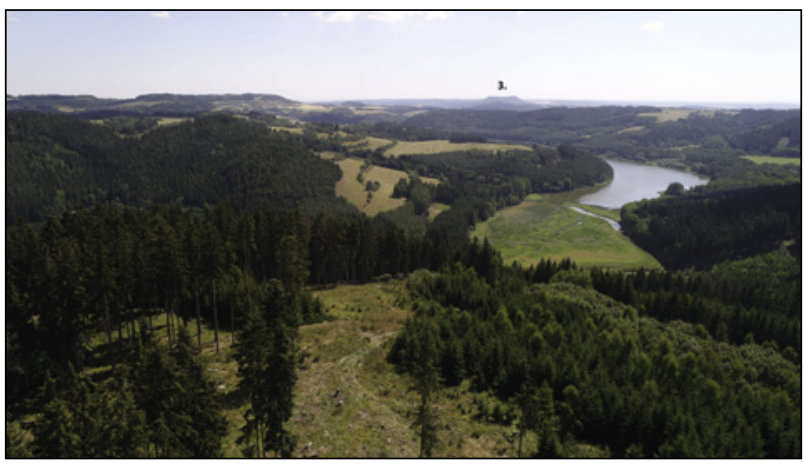

Obr. 8. Letecký pohled z nadhledu vrchu Čert'ák k východu. Č́slice označuje vrch Vladař, mocenské centrum pozdní doby halštatské, které je vzdálené $10 \mathrm{~km}$. Autor

$$
\text { F. Prekop. }
$$

Fig. 8. An aerial view from Čert'ák Hill towards the east. The number indicates the Vladař hillfort, which was a dominant site of the region in the Late Hallstatt period. Photo by F. Prekop.

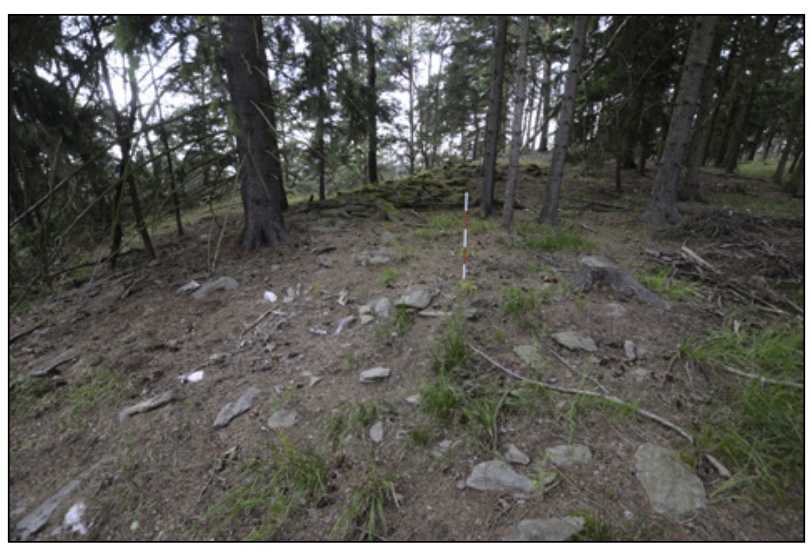

Obr. 10. Úsek nejlépe dochovaného ohrazení. Jihozápadní kout areálu, pohled k severozápadu. Autor Filip Prekop. Fig. 10. The best preserved remains of the inner rampart in southwest area. View to the northwest. Photo by F. Prekop.

V jejím okolí jsme ale dosud nenašli žádné nálezy. Druhým objektem severního svahu je relikt upravené (?) terasy, stoupající od severovýchodu k jihozápadu (obr. 6: D), kde navazuje na vrcholové plató, nedaleko zmíněné vyhlídky. Terasa velmi pravděpodobně fixuje směr přístupové komunikace, která obcházela skalní výchoz SV vrcholku a na úrovni 591 m n. m. navazuje na dodnes využívanou lesní cestu. Stáří a vztah komunikace k osídlení vrcholové partie zůstává zatím nejasný.

\section{1. Exkavace}

Terénní výzkum se soustředil na povrchový sběr, začištění sedmi vývratů a provedení čtyř zjišs'ovacích sond. Ty dosahovaly jednotných rozměrů $1 \times 1 \mathrm{~m}(o b r .6 ; 11)$. Výzkum doprovázela plošná detektorová prospekce, která ale kromě několika zcela recentních nálezů nepřinesla žádné archeologicky významné zjištění. 


\section{1. 1. Sonda 1}

První sondu jsme vytyčili v centrální části vnitřní ohraničené plochy, $\mathrm{v}$ místech koncentrace keramických fragmentů prì povrchovém průzkumu. Hloubka sondy byla $0,45 \mathrm{~m}$. Rozlišovali jsme dvě hlavní stratigrafické vrstvy. Svrchní lesní půda (101) světle šedohnědé barvy byla výrazně hlinitá. Druhou polovinu profilu tvořila písčitá hlína oranžovohnědé barvy (103), kterou lze považovat za kulturní vrstvu. Na rozhraní obou stratigrafických jednotek se v jižním profilu vyrýsoval pozůstatek organického materiálu tmavohnědé barvy, který byl pravděpodobně pozůstatkem zetleného kořene. Sonda dosáhla podloží (104), které bylo světle žlutohnědé barvy a písčitého materiálu s prúměsí slíd-

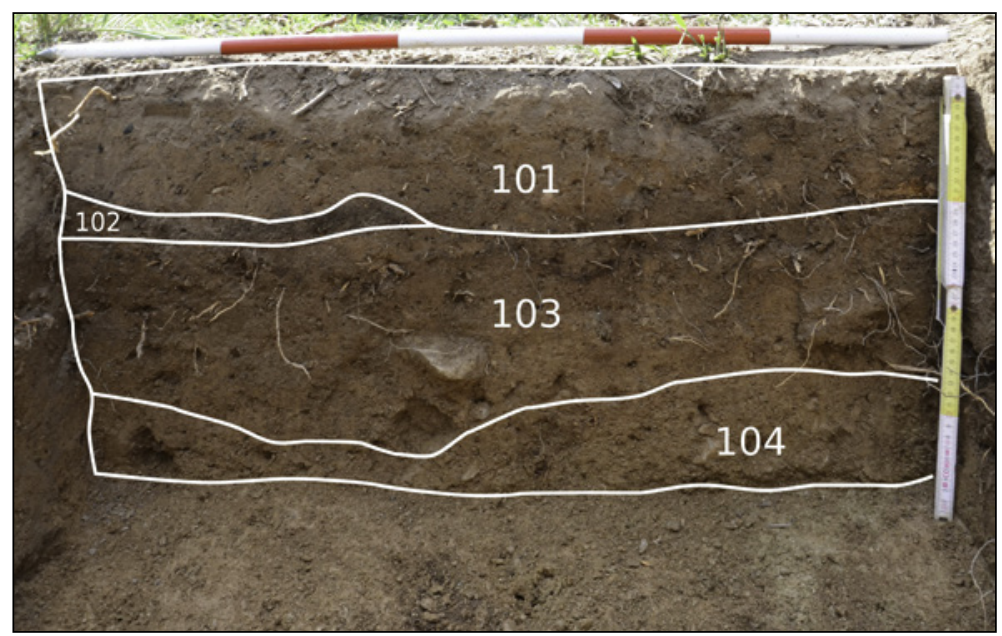

Obr. 11. Západní profil sondy 1 s rozhraními jednotlivých stratigrafických jednotek. Vytvořil F. Prekop.

Fig. 11. The west section of the trench No. 1 with delimited layers.

Created by F. Prekop.

natých kamínků. Ze sondy 1 pochází celkem 77 fragmentů keramiky, ze kterých bylo 16 morfologicky zařaditelných. Charakteristické jsou např́klad fragmenty den široce rozevřených misek (obr.12:101_2, 101_4), několik fragmentů s horizontální plastickou lištou (obr.12:103_8,103_9) nebo část výdutě s rovnoběžným rastrem hlubších a jemných rýh (obr.12: 101_5).

\section{1. 2. Sonda 2}

Sondu 2 jsme umístili do prostoru vnějš́ího ohrazeného areálu v blízkosti vývratu, kde rovněž byla na povrchu nalezena keramika. Hloubka sondy dosahovala $0,6 \mathrm{~m}$. Svrchní vrstva 201 byla šedohnědá hlína, smíchaná s lesní hrabankou po vývratu. Mocnost vrstvy byla 1 až $5 \mathrm{~cm}$. V hlubší partii profilu byla středně oranžovohnědá písčitá hlína, která zaujímala príibližně polovinu mocnosti. Nejhlubší část profilu tvořilo již zvětralé podloží v podobě sypké, světle žlutohnědé písčité hlíny s rozměrnými kameny. Nálezy se vyskytovaly pouze ve svrchní vrstvě 201 a následně ve vrstvě 202. Bohužel, kromě nevýrazného fragmentu hrany dna, všech 17 fragmentů keramiky postrádalo výzdobu či specifický tvar.

\section{1. 3. Sonda 3}

Třetí sonda byla položena v jihozápadním koutu vnitřního ohrazeného areálu, príibližně $10 \mathrm{~m}$ od jižního valu a 15 m od západního valu. Kromě lesní hrabanky (301) opět zabírala svrchní polovinu profilu sondy světle šedohnědá hlína s menším množstvím kamenů. Ve spodní polovině sondy se četně vyskytovaly kameny a středně oranžovohnědá písčitá hlína (303). Nejvíce nálezů jsme zachytili ve vrstvě 303, a to 78 kusů. Dalších 32 fragmentů pocházelo také z vrstvy 302. Charakteristické byly především zlomky okrajů misek s dovnitř zataženým okrajem (obr.12: 303_3) nebo s promačkávanou plastickou lištou (obr. 12: 303_4, 303_7).

\subsection{Sonda 4}

Sondu 4 jsme realizovali v severozápadním okraji ohrazené plochy, přibližně $10 \mathrm{~m}$ od západní ostré hrany vrcholové plošiny a $40 \mathrm{~m}$ od jejího severního okraje (obr. ๑). Dno sondy nebylo vodorovné. Snižovalo se od východu k západu v rozmezí hl. 0,2 až $0,4 \mathrm{~m}$. Vrstvy vykazovaly obdobné vlastnosti jako v předchozích př́padech. Pod lesní hrabankou se vyskytovala středně oranžová písčitá hlína (402). Ta plynule přecházela do sterilní vrstvy jasně okrového písčitého podloží. Nálezy jsme zachytili výhradně ve vrstvě 402 . Z celkem 56 fragmentů bylo 12 typických. Jsou to zlomky s dovnitř zataženým okrajem (obr.13:402_2) nebo odsazená dna (obr.13:402_1) či dovnitř prohnutá (obr. 13: 402_5). 


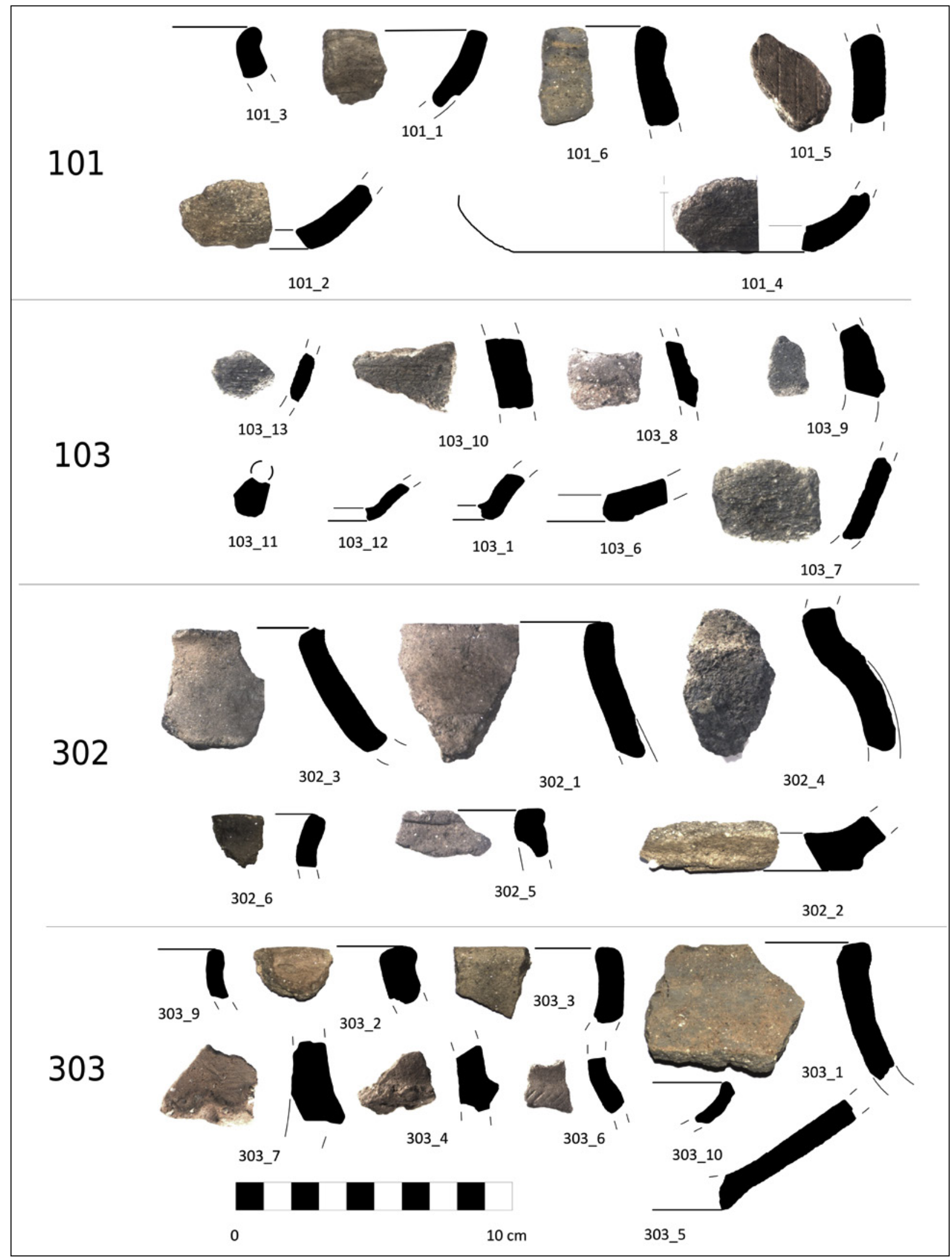

Obr. 12. Výběr typických fragmentů vrstev sondy 1 a sondy 3. Dokumentace provedená pomocí Laser Aided profiler (LAP). Vytvoŕil F. Prekop

Fig. 12. The range of pottery fragments from trench No. 1 and trench No. 3. The fragments were documented by using Laser Aided profiler (LAP). Created by F. Prekop. 


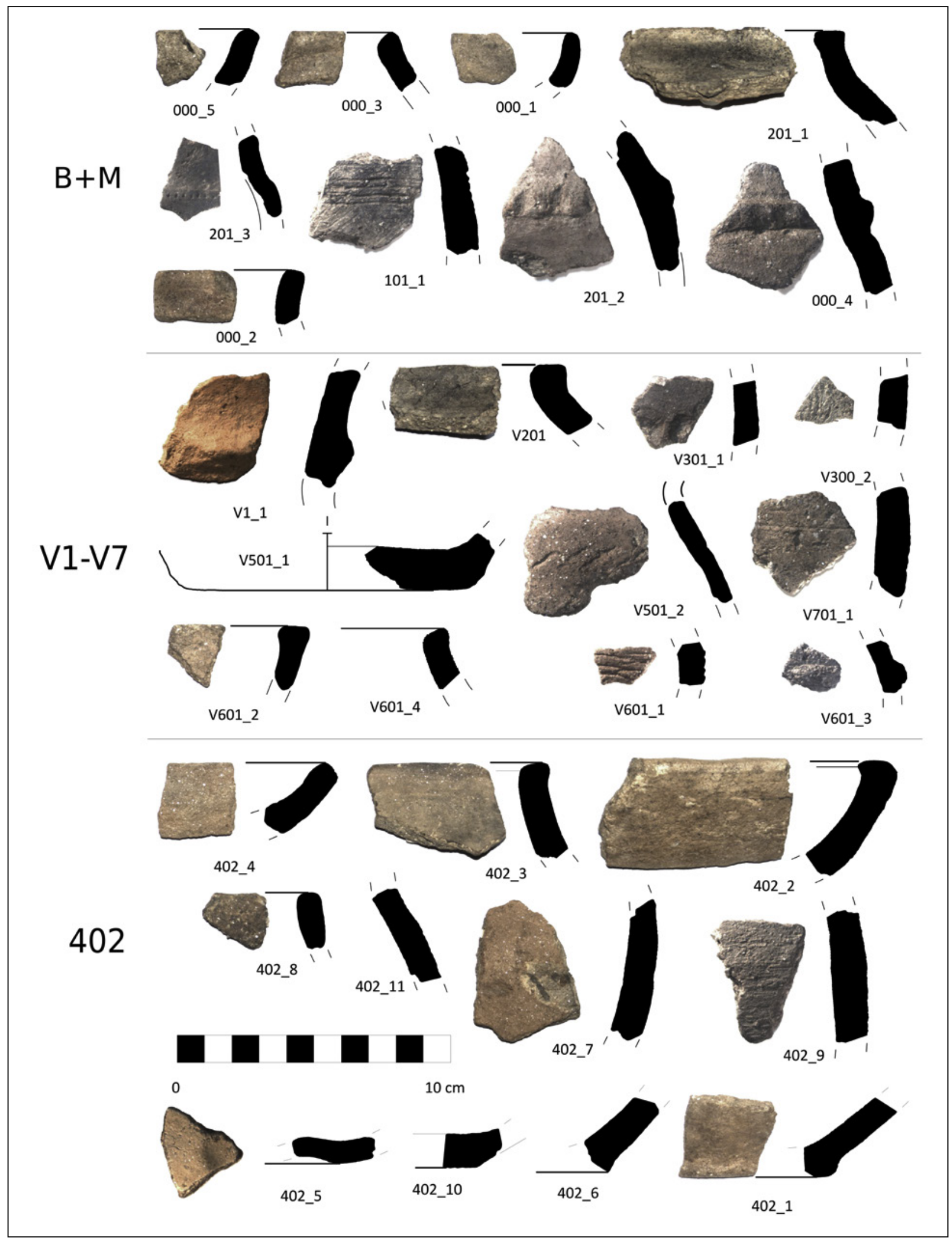

Obr. 13. Výběr typických fragmentů z předhradí, akce M. Metličky a J. Bašty $(M+B)$, vývratů (V1 - V7) a stratigrafické jednotky 402, sondy č. 4. Zpracováno pomocí přístroje LAP. Author F. Prekop.

Fig. 13. The range of pottery fragments from the outer fortified area, gathered by M. Metlička and J. Bašta (M+B); from places with uprooted trees $(\mathrm{V} 1-\mathrm{V} 7)$ and from the trench No. 4, context 402. The documentation of fragments by using Laser Aided profiler (LAP). Author F. Prekop. 


\subsection{Začištění existujících vývratů}

Součástí výzkumu byla také revize existujících vývratů v okolí vrcholové partie Čert’áku. Výskyt keramiky se potvrdil u všech z nich. Dvojice vývratů 1 a 2 se nachází v blízkosti JZ okraje, vně ohrazené plochy. Přestože právě zde došlo k prvním sběrům keramiky, patří situace $\mathrm{k}$ těm nejchudším. Zajímavý je fragment s promačkávanou plastickou lištou (obr.13: V1_1).

Vývrat č. 3 se nacházel přibližně v centru vnější ohrazené plochy. Pochází z něho 10 keramických fragmentů. Vývrat č. 4 se nacházel přibližně $25 \mathrm{~m}$ západně od vývratu č. 3, blíže $\mathrm{k}$ valu vnitřního opevnění. Vývraty 5 a 6 se nacházely v centrální části vnitřní ohrazené plochy a jsou z nich nejpočetnějšś kolekce movitých nálezů. $Z$ vývratu 5 pochází devět keramických fragmentů, Vývrat č. 6 patří k nejbohatším identifikovaným situacím. Z jeho začištění jsme získali soubor 44 keramických fragmentů. K charakteristickým zlomkům patř́ jistě část výduti s hlazeným povrchem, šedivé barvy s řadou důlků (obr.13: V301_1), podhrdlí nádoby s pásem šikmých rýh (obr.13: V501_2) nebo zduřelý, horizontálně seř́znutý okraj (obr. 13: V201).

\section{2. Odkryv ve vnější ohrazené ploše}

$\mathrm{Na}$ jihovýchodní kout vnějšího ohrazení se zaměřil Jaroslav Bašta při svém samostatném průzkumu lokality po neformálním zjištění jejího objevu. Nejdříve provedl začištění místa porušení terénu vzniklé stahováním dřeva (obr. 6: 1) a začištění staršího vývratu, cca $20 \mathrm{~m}$ západně od první polohy (obr. 6: 2). Společně s Milanem Metličkou odhalili další porušení vzniklé pokračující těžbou dřeva, kde provedli mikrosondu $40 \times 40 \mathrm{~cm}(o b r .6: 3)$. Kromě nálezů z povrchu identifikovali sypkou kulturní vrstvu světle hnědé barvy, která byla o něco tmavší než sypké podloží. Její mocnost určili na $25-30 \mathrm{~cm}$. Nad ní se nacházelo cca $10 \mathrm{~cm}$ lesního humusu (Bašta-Metlička 2018). Závěry i samotné nálezy nám autoři poskytli a my je začleňujeme jak do celkového plánu lokality (obr. O), tak př̌edstavené dokumentace nálezů (obr. 12: $B+M)$.

\section{Datace a rozbor nálezů}

Celkem doposud disponujeme 527 fragmenty keramiky ze zkoumané lokality, z nichž je 69 typických (graf 1). Zjišt’ovacími sondami jsme získali rámcovou představu o plošné distribuci movitých nálezů a povaze nadložních vrstev. Ve vnitřním areálu jsme zachytili vyšší počty keramických fragmentů než ve vnější ohrazené ploše. Z jiného úhlu pohledu je patrná opakovaně doložená zvýšená koncentrace výskytu nálezů príi vnitřním obvodu opevnění, než ve středu ohrazených ploch. Do jaké míry je situace zkreslená působením postdepozičních transformací nelze nyní s určitostí ŕíci.

Časové zařazení keramického souboru, potažmo celé lokality se dosud opírá pouze o morfologické vyhodnocení typických keramických nálezů. Vztah k budování opevnění zatím pouze dedukujeme. Charakter nálezů i jejich výzdoby se nijak nevymyká poznání obsahu Reineckeho stupně Ha D (Ha D2-3), který dosahuje výrazně homogenního výrazu napříč celým územím Čech (Venclová ed. a kol. 2008, 100). Řadu paralel k našim nálezům spatřujeme v souborech blízkých i vzdálenějších lokalit západních Čech uvedeného období (Chytráček - Metlička 2004).

Hned v několika morfologických znacích námi získaného souboru nacházíme blízké analogie v publikovaných výzkumech osídlení Vladaře (Chytráček - Šmejda 2005; Chytráček - Danielisová - Pokorný a kol. 2012). První z nich je různě pojednaná vodorovná plastická lišta, která je převážně promačkávaná (obr. 12: 103_8, 103_9, 303_4, 303_7; obr. 13:000_4). Velmi podobné fragmenty obsahovala souvrství vrcholové plošiny hradiště Vladař v sondě 1, kde se rovněž nalezlo několik jejich variant provedení (Chytrácek et al. 2014, obr. 12: 19-21; 13: 20). Fragment plastické lišty hrotitého profilu s promačkáváním byl nalezený také například ve výplni sídlištního objektu ve zkoumané části vrcholového plató Vladaře (Chytráček et al. 2014, 286). Přímou analogii můžeme spatřovat ve fragmentu z ohrazené lokality Podštěly - Jezerský vrch (Chytráček - Metlička 2004, 236, obr. 116: 8, 9). Další velmi podobný fragment pochází např́iklad také ze stejně datované lokality Albrechtice, okres Klatovy (Chytráček-Metlička 2004, 143, obr. 10: 8).

Náš fragment vydutého dna nádoby (obr. 13: 402_5) má analogie v souboru z Vladaře, jak ze sondy na akropoli, tak v jedné z dřevěných komor nádrže z IV. předhradí (Chytráček et al. 2014, 290, obr. 11: 21; 304, obr: 23: 7). 
Část lomeného podhrdlí zdobeného motivem šikmých rýh má věrnou analogii např́klad ze souboru nálezů lokality Darmyšl, okr. Tachov (Chytráček - Metličea 2004, 158, obr. 27) nebo také zkoumaného ohrazeného dvorce ve Štítarech nad Radbuzou (Chytráček Metlickea 2004, 267, obr. 148; 263, obr. 44: 6).

Zajímavým motivem výzdoby, který se nám podařilo zachytit, je část výduti nádoby s jemným hřebenováním, lemovaným hlubšími rýhami (obr. 12: 101_5). Působí poněkud archaicky, ale rovněž se běžně nachází v keramických souborech razených do stejného chronologického stupně (Chytráček - Metlička 2004, 244, obr. 126:15; 121:11).

Drobný fragment z vrstvy 103 (obr. 12: 103_11), nese stopy po tenkém průchozím otvoru. Fragment považujeme za část cedníku nebo nakuřovadla, jenž je také známé z obdobných lokalit, přestože se nejedná o chronologicky citlivý prvek. Známe je z lokalit Rado-

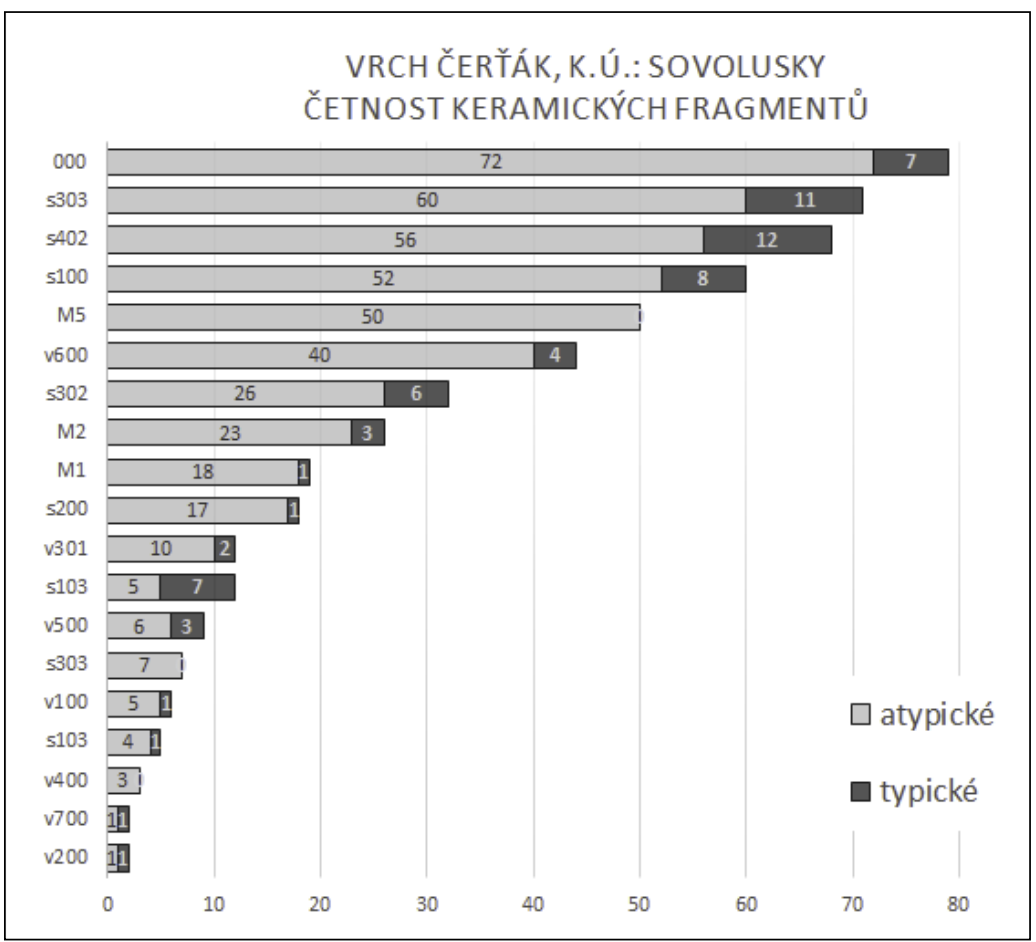

Graf 1. Početné zastoupení typických a atypických keramických fragmentů v identifikovaných stratigrafických jednotkách. Vytvořil F. Prekop.

Graph 1. Numerical representation of typical and atypical pottery fragments in identified stratigraphic units. Author F. Prekop. byčice, Plzeň - Hradiště nebo Planá-Radná (Chytráček - Metlička 2004, 219, obr. 97: 9; 238, obr. 119: 9).

Za specifikum našeho keramického souboru lze považovat vzácně se vyskytující motiv výzdoby důlky, at' samostatnými nebo $v$ řadách, které jsou jinde relativně běžné. $V$ našem prŕpadě jsme jej nalezly pouze $v$ jediném př́padě (obr. 13: V301_1).

\section{Rekonstrukce př́rodního prostředí}

Pokusili jsme se získat představu o přírodním prostředí oblasti provedením antrakologického a makrozbytkového rozboru. Dvojici drobných vzorků sedimentu o objemu 1,5 1 vyhodnotil Petr Kočár (Kočár 2019). Vzorky sedimentu byly flotačně proplaveny na sítu $0,25 \mathrm{~mm}$ a vysušeny při pokojové teplotě. Vzorky neobsahovaly makrozbytky rostlin. Pro antrakologickou analýzu byly vybrány zlomky uhlíků z frakce větší než $2 \mathrm{~mm}$. Uhlíky byly po provedení čerstvých lomných ploch (transversální, radiální a tangenciální zlom) přímo prohlíženy pod světelným mikroskopem uzpůsobeným pro prohližení v dopadajícím světle (episkopický mikroskop) při zvětšení 50×, 100× a 200×. Vzhledem ke křehkosti studovaného antrakologického materiálu nebyla početnost jednotlivých taxonů udávána pouze počtem zlomků uhlíku, ale také hmotnostně.

Vzorky obsahovaly zlomky uhlíků břízy (Betula), smrku (Picea), borovice (Pinus) a blíže neurčitelného jehličnanu (Conifera). Bližší poměr dřevin nebylo možné stanovit vzhledem k malému množství odebraných vzorků. Zdrojem dřeva pro výšinnou lokalitu byly blíže neidentifikovatelné lokální porosty jehličnanů snad smrčiny (smrk) a bory (borovice, bříza).

Přínosný vhled do přírodních podmínek mladšího zemědělského pravěku v širší sledované oblasti přinesly pylové analýzy z trojice odběrových míst při výzkumu osídlení Vladaře (Pokorný 2011, 269-308). K vrchu Čert’ák má nejbliže rozbor sedimentu z nově zakládaného rybníka z katastru obce Veselov (Pokorný 2011, 293-301; poloha "A”, obr. 2). Přestože jej nelze př́mo přenášet na námi sledovanou lokalitu, nezávisle dokládá lidskou přítomnost v další lokalitě 
mezi Vladařem a Čert’ákem. V úrovni odpovídající pomezí pozdní doby halštatské a doby laténské zde dochází $\mathrm{k}$ rapidní proměně krajiny. Úsek začíná doklady úplného zalesnění s převahou jehličnanů a následně se transformuje do kulturní, bylinně pestré krajiny, s doloženou prítomností polí, luk a pastvin v okolí odebraného profilu. Kulturní charakter si krajina okolo Veselova, obdobně jako v př́ípadě Vladaře, zachovala přibližně až do přelomu letopočtu (Pokorný 2011, 295).

\section{Halštatské osídlení regionu}

Vrch Čert’ák patří k zajímavé skupině lokalit zařazených do pozdní doby halštatské až časné doby laténské s prostorou vazbou na horní tok řeky Střely a jejích přítoků (obr. 2). Zvýšená intenzita přitomnosti člověka v této oblasti se tradičně spojuje s výskytem ložisek zlata, přestože přímý doklad jejich pravěké těžby chybí. Zlaté milodary odpovídající svou ryzostí lokálním ložiskům byly doložené pouze v rámci poněkud vzdáleného pohřebiště Manětín-Hrádek (Soudská 1994). I v níže popsané skupině lokalit spatřujeme vzájemnou diferenciaci, která odrážela i rozdílnou úlohu $\mathrm{v}$ tehdejší společnosti.

Z doposud známých lokalit má k námi zkoumané lokalitě nejblíže pohřebiště ze severozápadního okraje stejné obce Sovolusky (obr. 3: 2). Nachází se na opačném břehu řeky, ve vzdálenosti cca $1,5 \mathrm{~km}$ a v přímé pohledové vazbě brání dílčí kupa Muriňák, nazývaná také Hůrka (obr. 3: B). Pohřebiště samotné zaujímá hranu dílčího spočinku táhlého jižního svahu Jesíneckého vrchu (obr. 3: A), v jehož okolí bylo neúspěšně hledané soudobé sídliště (Beneš 1969a, 149). Námi publikovaný plán pohřebiště jej nově lokalizuje s geografickými souřadnicemi systému S-JTSK, jelikož dosud byl lokalizován pouze relativně vůči dnes již zaniklým hospodářským budovám.

Pohřebiště patří ke stěžejním oporám chronologického členění pozdní doby halštatské v Čechách a jeho obsah byl detailně publikovaný v r. 1969 (Beneš 1969a; 1969b; Soudská 1969). Ukládání zdejších hrobů je řazené do časového intervalu od Ha D2-3 až po Lt A - Lt B (Beneš 1969a, 160).

Hlavní výzkumné práce zde vedl Antonín Beneš v letech 1961 a 1962, kterým předcházela menší záchranná akce Norberta Maška z Karlovarského muzea v roce 1958. Bohužel, obsah vícero hrobů vyzvedli místní pracovníci tehdejšího jednotného zemědělského družstva. Ani Antonínu Benešovi se tak 9 hrobů z celkem 32 nepodařilo bliže prostorově určit (Beneš 1969a, 134). Společným rysem všech hrobů bylo užívání kamene v konstrukci nebo zásypu převážně mísovitých, mělkých hrobových jam. Výbavy hrobů byly poměrně chudé. Nejvyšší počet celých nádob dosahoval hodnoty 4 (hrob 21). Jiné než keramické nálezy obsahovaly pouze 4 hroby. Kromě hrobu 17 se

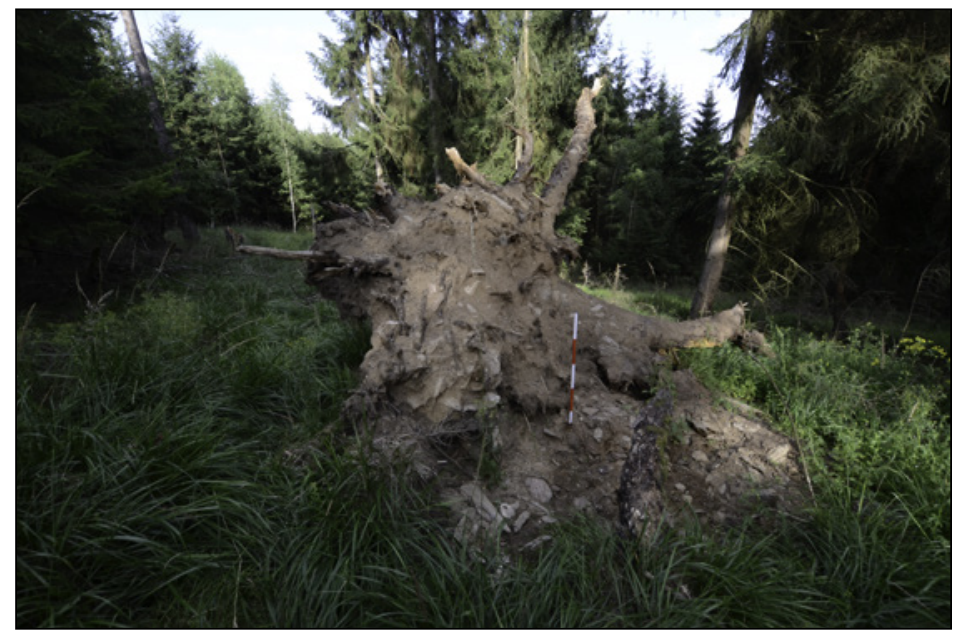

Obr. 14. Vývrat č. 1 (V1), místo prvních nálezů keramických fragmentů. Pohled k východu, červenec 2018. Autor F. Prekop.

Fig. 14. The uprooted tree (V1), where the first pottery findings came from. View to the east, July 2018. Photo by F. Prekop. tyto hroby nacházely vzájemně blízko sebe, v centrální části pohřebiště (obr. 4). Bohužel, jediný celistvý náramek z bronzového plechu (hrob 10) i část tyčinkovitého náramku (hrob 20) byly ztraceny již v 60. letech (Benes 1969a, $138,142)$. Další tři drobné fragmenty bronzového plechu s geometrickou výzdobou, patrně z turbanovitého náramku, pocházely ještě z blízkého hrobu 21. Poněkud dislokovaný hrob č. 17 obsahoval spolu s fragmenty několika keramických nádob blíže neurčitou část železného předmětu (Beně̌ 1969a, 140). Je zajímavé, že skupina hrobů s bronzovými šperky se nachází v centrální části pohřebiště, a to nedaleko výjimečně hlubokého hrobu č. 31, jehož stěny i dno hrobové jámy bylo vyloženo kameny a on samotný žádný kovový artefakt neobsahoval (Beneš 1969a). 
Zdejší vưdčí ústřední úlohu v pozdní době halštatské až časné době laténské plnil vrch Vladař, který je vzdálený od Čert'áku príibližně $10 \mathrm{~km}$ východním směrem (obr. 2, lok. 3). Není bez zajímavosti, že kromě charakteru nálezů spojuje obě lokality vzájemná viditelnost. Opevněný areál na Vladaři vznikl prokazatelně již ve střední době bronzové a byl obývaný víceméně kontinuálně až do přelomu letopočtů. Největší rozmach osídlení odpovídá intervalu let 400 až 200 př. n. 1. (Chytráček - Danielisová - Pokorný a kol. 2012). V této době disponoval kromě opevněné vrcholové plošiny také složitým komplexem opevnění jeho západního a severního úpatí. Celková ohrazená plocha dosahovala úctyhodných 115 ha. Nadregionální význam Vladaře podtrhuje také několik nalezených importů, mezi které se řadí bronzová maskoidní soška pyxidy s vyobrazenou prílbou typu Negau, fragment jantarového korálku nebo mladolaténský meč (Chytráček - Šmejda 2005, 43).

Soustředíme-li se na výšinné lokality, musíme uvést již dřive zmiňované výšinné sídliště Podštěly - Jezerský vrch (Soukupová Baštová 1984; Chytrácée - Metlička 2004, 101). To leží stejně jako Čert’ák nad údolím Střely a to asi 5,5 km SV od Vladaře a od Čert’áku je vzdáleno asi 14 km na VSV (obr. 2: 5). Je považováno za součást stejného sídelního regionu jako Vladař. Bohužel, archeologická zjištění, stejně jako jejich vztah k obtížně rozpoznatelným reliktům opevnění, jsou velmi vágní (Augustinová 2014, 20-22). Podobným př́ípadem je také drobná lokalita Chyše - Na střelnici (Baštová 1985, 160), která sice není spolehlivě datována, ale tato ostrožna s jednoduchým prúmým valem má rovněž úzkou vazbu na tok řeky Střely a rozprostírá se v těsné blízkosti Vladaře, cca 11,5 km východně od Čert’áku (obr. 2: 4).

V okolí klíčové polohy Vladař byla kromě zmíněných pohřebišt' Manětín - Hrádek (Soudská 1994) a pohřebiště na k. ú. Sovolusky, nedaleko polohy Čert’ák (viz výše) identifikována další poloha s halštatským pohřbem (obr. 2: 10). Jedná se o izolovaný, blíže neurčený, nález žárového hrobu z katastru obce Novosedly (Plesl-Hájek - Martínek 1983, 51).

Pozdně halštatské sídelní aktivity jsou registrovány především v okolí řeky Střely. Jedná se o relikty sídliště, které byly objeveny v cihelně u obce Podštěly (obr. 2: ๑). Z asi 20 sídlištních jam, které zde byly zničeny, se podařilo zachránit pozdně halštatskou keramiku pouze z jedné z nich (Plesl - Hájek - Martinek 1983, 55). Posuneme-li se proti proudu Střely směrem $\mathrm{k}$ hradišti Čert’ák, nacházíme nálezy z doby halštatské až časně laténské na katastru města Žlutice (obr. 2: 9). Některé z nich však nejsou přesně lokalizované, nebo nevíme jistě, o jaký kontext se jedná (Plesl-Hájek - Martinek 1983, 81). Nejblíže ohrazené poloze na Čert’áku se nachází lokalita Verušice, kde byly při povrchových sběrech zachyceny zlomky halštatské keramiky (Plesl - Hájek - Martinek 1983, 77).

\section{Závěr}

Náš př́ispěvek představuje první zjištění ze zcela nového výšinného ohrazeného sídliště na vrchu Čert’ák, katastru Sovolusky, v okrese Karlovy Vary, kterou se, jako mnoho jiných, podařilo identifikovat díky archeologické interpretaci digitálního modelu terénu z dat leteckého laserového skenování. Díky němu je možné archeologicky vyhodnocovat i dlouhodobě obtižně př́stupné oblasti České republiky, ke kterým horní tok řeky Střely bezesporu patří. Ohrazený areál se dělí na dvě nestejně velké části s jádrovou plochou vázanou na samotný vrchol a západní část vrcholové plošiny. Východní ohrazenou část lze považovat za předhradí.

Provedený povrchový průzkum a několik zjišt’ovacích sond $\mathrm{v}$ místech existujících terénních porušení prìnesl soubor více než 500 kusů keramických nálezů, jenž lze relativně dobře zařadit do období pozdní doby halštatské (Ha D2/3). Konstrukce ohrazení nebyla doposud zkoumána a její spojení s doklady osídlení je tak zatím pouze hypotetické, ale vzhledem $\mathrm{k}$ absenci dokladů jiné chronologické komponenty velmi pravděpodobné. Nelze zcela vyloučit, že budoucí výzkum odhalí postupné budování obou ohrazených částí sledovaného výšinného sídliště. Bohužel, ani náš výzkum nepřinesl jasný doklad vazby osídlení na exploataci lokálních nalezišt' zlata. Přesto uvedenou hypotézu nijak nevyvracíme.

Objevené výšinné hradiště zajímavě doplňuje mozaiku známých lokalit daného období. Společně s nedalekým pohřebištěm v Sovoluskách tvoři Čert’ák doposud nejzápadněji položenou lokalitu z okruhu lokalit spadajících pod kontrolu mocenského centra Vladař, a to z doby jeho největší intenzity obývání.

Výzvou dalších výzkumů bude jistě získat absolutní datování objevených komponent památky, př́padně prohloubit poznání prrírodního prostředí lokality a zopakovat detektorovou prospekci památky. 


\section{Poděkování}

Příspěvek vznikl v rámci dílč́ho cíle "Terénní identifikace a dokumentace vybraných archeologických lokalit a opomíjených archeologických památek v krajině za pomoci standardních a nových dokumentačních metod" výzkumné oblasti I. Archeologie financované z institucionální podpory Ministerstva kultury na dlouhodobý koncepční rozvoj (IP DKRVO).

\section{Bibliografie}

Augustinová, A. 2014: Hradiště Podštěly v Karlovarském kraji - základní prospekce, aktuální zhodnocení nálezů a sídelní kontext. Bakalářská práce. Univerzita Karlova v Praze. Filozofická fakulta. Ústav pro Archeologii.

Bašta, J. - Metlickea, M. 2018: Vrch Čert’ák, k.ú. Sovolusky. Zpráva o archeologické akci. Archiv NPÚ, ú.o.p. v Lokti.

Beneš, A. 1969a: Pozdně halštatské žárové pohřebiště v Sovoluskách, okres Karlovy Vary. Památky archeologické 60, 134-163.

Beneš, A. 1969b: Addenda k pozdně halštatskému žárovému pohřebišti v Sovoluskách, okres Karlovy Vary. Archeologické rozhledy 21, 678-679.

Čtverák, V. et al. 2003: Encyklopedie hradišt’ v Čechách. Praha.

Chytráček - Danielisová - Pokorný a kol. 2012 - Chytráček, M. - Danielisová, A. - Pokorný, P. - Kocárí, P. - Kyselý, R. - Kyncl, T. - Sádlo, J. - Šmejda, L. - Zavrel, J. 2012: Vzestupy a pády regionálního mocenského centra: přehled současného stavu poznání pravěkého opevněného areálu na Vladaři v západních Čechách. Památky archeologické 103, 273-338.

Chytráček, M. - Metlickea, M. 2004: Die Höhensiedlungen der Hallstatt- und Latènezeit in Westböhmen. Archeologický ústav AV ČR, Památky archeologické. Supplementum 16, 303.

Chyträ́cek, M. - Šmejda, L. 2005: Opevněný areál na Vladaři a jeho zázemí: k poznání sídelních struktur doby bronzové a železné na horním toku Střely v západních Čechách. Archeologické rozhledy 57, 3-56.

Kočár, P. 2019: Archeobotanická analýza, Čert’ák, k.ú.: Sovolusky. Nálezová zpráva. Archiv NPÚ ú.o.p. v Lokti.

Matèjui, J. - Hradecké, P. - Melichar, V. 2016: Doupovské hory. Praha.

Plesl, E. - Hájek, L. - Martinek, J. 1983: Pravěk Karlovarska a Sokolovska a katalog archeologických sbírek muzeí v Karlových Varech a Sokolově. Karlovy Vary.

Pokorný, P. 2011: Neklidné časy: kapitoly ze společných dějin přírody a lidí. Praha.

Prekop, F. - Krištuf, P. - Peksa, V. - Eigner, J. - Kočár, P. 2017: Nové doklady osídlení výšinných poloh na Karlovarsku - polykulturní lokality Orlík a Šibeniční vrch u obce Valeč v Čechách. Archeologie západních Čech 12, 41-67.

Prekop, F. - Krištuf, P. - Peksa, V. 2018: Výšinný ohrazený areál na Kružínském vrchu, k. ú. Skytaly. Archeologie západních Čech. 9/2, 16-26.

Soudská, E. 1969: K třídění plochých pozdně halštatských žárových pohřebišt’ v severozápadních Čechách. Památky archeologické 60, 164-196.

Soudská, E. 1994: Die Anfänge der keltischen Zivilisation in Böhmen: The beginnings of Celtic civilisation in Bohemia $=$ Počátky keltské civilizace $\mathrm{v}$ Čechách. Prag.

Venclová, N. (ed.) a kool. 2008: Archeologie pravěkých Čech. 6. Doba halštatská. Praha. 


\section{Internetové zdroje}

Baštová, Dara 1985: Dokument C-TX-198602875. [sekundární zdroj]. Dostupné z: https://digiarchiv.aiscr.cz/id/CTX-198602875. (1. 7. 2021)

Soukupová Baštová, Dara 1984: Dokument C-TX-198501705. [sekundární zdroj]. Dostupné z: https://digiarchiv. aiscr.cz/id/C-TX-198501705. (1. 7. 2021)

Laser Aided profiler, zdroj: https://www.laseraidedprofiler.com/ (1. 7. 2021)

\section{Mapové podklady}

Analýzy výškopisu. zdroj: https://ags.cuzk.cz/av/ (1. 7. 2021)

Císařské otisky Stabilního katastru. zdroj: http://oldmaps.geolab.cz/; list 3950_3 https://ags.cuzk.cz/archiv/ (1.7. 2021)

Geologická mapa Čech. ID geologické jednotky 785. zdroj: https://mapy.geology.cz/geocr50/ (1. 7. 2021)

Topografická díla systému S-1952. List M33-63C. zdroj: https://ags.cuzk.cz/archiv/ (1. 7. 2021)

První vojenské (josefské) mapování. List č. 102. zdroj: http://oldmaps.geolab.cz/ (1. 7. 2021)

Třetí vojenské mapování. list 3950_3. zdroj: http://oldmaps.geolab.cz/ (1. 7. 2021)

\section{Summary}

The article presents the evidence of a new hillfort site from Late Hallstatt period in West Bohemia, Sovolusky-Čert'ák, Karlovy Vary district. This site has been discovered on a digital terrain model , called „Analýzy výškopisu", freely accessible for the whole area of the Czech Republic through websites. It was made in basic raster, where one pixel represents 4 square meters in real landscape. The data source comes from Airborne laser scanning (LiDAR), organized and published by the Czech Geodetic and Cadastral Office.

The existence of the hillfort was proved by field research. First step of the work was creating a detailed digital terrain model (DTM), using a „natural neighbour” algorithm to create a mesh with raster where each pixel represents a 0.5 square meter of real landscape. Visualisation of DTM is a compound of hillshade with triple extended altitude, local relief model and skyview factor. The features in the resulting map were confirmed by field observation with GPS location.

The aims of the survey were to precisely locate hillfort's ramparts and collect artefacts to date the site. The rampart lines delimit the inner and external part. The inner area covers the hilltop and the west side of the top platform, reaching the area of $1.4 \mathrm{ha}$. Probably the gate remains can be recognised in the southwest corner. The external part defines approximately 2.3 ha of fortified area.

Although a metal detector was also used the collected artefacts are pottery fragments only, which come from surface survey and revision of uprooted trees. In four places an excavation of 1 square meter was pursued. The layer with findings was repeatedly documented. We analysed more than 500 pieces of pottery in total, which relatively clearly corresponds with the known finds from surrounding sites of the same period. The Čert'ák hillfort confirms that in the Late Hallstatt period the upper part of Strela River was densely settled with fortified sites closely connected to each other. 